\title{
Jaringan komunikasi dalam pengelolaan perencanaan program penanggulangan kemiskinan di Provinsi Sulawesi Barat
}

\author{
Erwin Rasyid ${ }^{1}$, Partini ${ }^{2}$, Fransiskus Trisakti Haryadi ${ }^{3}$, Achmad Zulfikar ${ }^{4}$ \\ ${ }^{1}$ Universitas Aisyiyah Yogyakarta, Yogyakarta, Indonesia \\ ${ }^{2,3}$ Universitas Gadjah Mada, Yogyakarta, Indonesia \\ ${ }^{4}$ Universitas Teknologi Sulawesi, Makassar, Indonesia
}

\begin{abstract}
ABSTRAK
Wacana desentralisasi pembangunan berkembang seiring dengan hadirnya Undang-Undang Nomor 22 Tahun 1999 tentang Otonomi Daerah. Fenomena desentralisasi pembangunan yang diwujudkan dengan kebijakan pemekaran wilayah, saat ini masih menyisahkan berbagai macam persoalan. Kemiskinan menjadi persoalan fundamental yang banyak dihadapi oleh beberapa Daerah Otonomi Baru. Sebagai upaya untuk menanggulangi persoalan kemiskinan, Pemerintah Daerah Provinsi Sulawesi Barat merencanakan program strategis yang diberi nama Program Marasa. Perencanaan Program Marasa melibatkan koordinasi lintas sektor, sehingga berdampak pada adanya persoalan ego sektoral antarinstansi dalam upaya komunikasi yang terjadi di antara unsur Organisasi Perangkat Daerah (OPD). Tujuan penelitian ini adalah untuk menggambarkan sosiogram atau struktur jaringan komunikasi OPD Pemerintah Provinsi Sulawesi Barat dalam merencanakan Program Marasa. Metode yang digunakan dalam penelitian ini adalah deskriptif kuantitatif dengan pendekatan analisis jaringan komunikasi. Hasil penelitian menunjukkan bahwa terdapat dua titik sentral dalam jaringan komunikasi antar OPD Provinsi Sulawesi Barat, yaitu Badan Perencana Pembangunan Daerah (Bappeda) serta Dinas Pemberdayaan Masyarakat dan Desa (DPMD). Bappeda berperan sebagai opinion leader yang berpengaruh dalam menentukan program yang dapat diintegrasikan ke dalam Desa Marasa. Bappeda juga berperan sebagai broker yang menyampaikan informasi terkait penyusunan Program Marasa ke OPD lainnya. Berbeda dengan Bappeda, DPMD berperan sebagai gate keepers dengan jaringan ego jauh lebih kompleks dibandingkan dengan jaringan ego Bappeda. Penelitian ini menunjukkan bahwa pemerintah perlu mendesain strategi komunikasi yang mampu meningkatkan efektivitas proses koordinasi antarlembaga pemerintahan.
\end{abstract}

Kata-kata Kunci: Desentralisasi; jaringan komunikasi; kemiskinan; program marasa; Sulawesi Barat

\section{Communication network in managing program of poverty reduction planning in the West Sulawesi Province}

\begin{abstract}
The discourse of development decentralization developed with the presence of Law No - 22 of 1999 on Regional Autonomy. Decentralization development, which is embodied by the policy of regional expansion, leaving various problems. Poverty is a fundamental problem that is often faced by several New Autonomous Regions. In tackling poverty, the Regional Government of West Sulawesi Province is planning a strategic program called the Marasa Program, which involves cross-sectoral coordination so that it impacts on the existence of sectoral ego problems between agencies in communication efforts that occur among elements of the Regional Apparatus Organization (OPD). The purpose of this study is to describe the sociogram or structure of the West Sulawesi Provincial OPD communication network in planning the Marasa Program. The method used in this research is a quantitative descriptive analysis approach to communication networks. The results show that there are two central points in the communication network between West Sulawesi Province $O P D$, namely the Regional Development Planning Agency (Bappeda) and the Community and Village Empowerment Agency (DPMD). Bappeda acts as an influential opinion leader in determining programs that can be integrated into Marasa Village. Bappeda also acts as a broker who conveys information related to the preparation of the Marasa Program to other OPDs. In contrast to Bappeda, DPMD acts as a gatekeeper with ego networks much more complicated than Bappeda ego networks. This research shows that the government needs to design communication strategies that can improve the effectiveness of the coordination process between government agencies.
\end{abstract}

Keywords: Decentralization; communication network; marasa program; poverty; West Sulawesi

Korespondensi: Erwin Rasyid, S.I.Kom., M.Sc. Universitas 'Aisyiyah Yogyakarta. Jl. Siliwangi (Ring Road Barat) No.63 Mlangi, Nogotirto, Gamping, Sleman, Yogyakarta. 55292.Email: erwin.rasyid@unisayogya. ac.id 


\section{PENDAHULUAN}

Laju pertumbuhan daerah otonomi baru mengalami peningkatan yang sangat signifikan pasca disahkannya Undang-Undang Nomor 22 Tahun 1999. Jumlah daerah otonom di Indonesia pada tahun 1999, hanya sekitar 26 provinsi, 268 kabupaten dan 73 kota. Kemudian pada tahun 2014 terjadi peningkatan hampir sekitar 50 persen daerah otonom di Indonesia. Namun pada tahun 2017, Pemerintah resmi mengeluarkan kebijakan moratorium terhadap pemekaran atau pembentukan daerah otonomi baru.

Tren lain dari tuntutan pemekaran daerah banyak berasal dari luar pulau Jawa (Abdullah, 2011). Sulawesimenjadi salah satukawasan yang banyak mengajukan permohonan pemekaran daerah kepada Pemerintah Pusat. Kawasan ini terdiri dari 6 provinsi yaitu Sulawesi Selatan, Sulawesi Tengah, Sulawesi Tenggara, Sulawesi Utara, Gorontalo dan Sulawesi Barat. Sulawesi Barat adalah provinsi terakhir yang terbentuk di kawasan ini. Sulawesi Barat merupakan hasil pemekaran dari Provinsi Sulawesi Selatan.

Daerah otonomi di pulau Sulawesi terpengaruh adanya kebijakan pemekaran daerah. Pada tahun 2000, Provinsi Gorontalo memisahkan diri dari Sulawesi Utara dan Sulawesi Selatan bermunculan beberapa gerakan otonomi daerah dengan diikuti tuntutan-tuntutan paling kuat datang dari bagian barat-laut maupun timur-laut daerah itu. Pada tahun 1999, Kabupaten Mamuju, Majene dan Polewali-Mamasa menuntut otonomi dari Sulawesi Selatan dengan tujuan pembentukan Provinsi Sulawesi Barat (Sulaiman, 2017). Daerah Balanipa, Sulawesi Barat juga mengalami dinamika internal dan eksternal dalam proses pemekarannya (Fibrianti, 2017).

Ada beberapa faktor yang mendorong terbentuknya Provinsi Sulawesi Barat antara lain: jarak yang cukup jauh dari Ibukota Provinsi Sulawesi Selatan (Nawawi, 2015). Kemudian kondisi geografisnya yang didominasi oleh pegunungan dengan infrastruktur jalan yang buruk. Mayoritas penduduknya terdiri dari etnis Mandar, dan beberapa kelompok sub etnik lainnya yang lebih egaliter sehingga sering berbeda sikap dengan kelompok etnis mayoritas dan dominan dari provinsi Induk (Bugis dan Makassar).

Permasalahan krusial yang sering muncul dalam proses pembentukan daerah otonomi baru (DOB) adalah kuatnya unsur politis dibanding sisi teknis prosedural dalam perencanaan dan penataan pemekaran daerah tersebut. Kebijakan pemekaran wilayah semakin membuka peluang terjadinya bureaucratic dan political rentseeking yang berimplikasi terhadap adanya praktik memperoleh keuntungan dana baik dari alokasi pemerintah pusat maupun dari pendapatan asli daerah tersebut (Fitrani, Hofman, \& Kaiser, 2005). UU Otonomi Daerah tidak hanya sekedar mendukung maraknya praktik pembentukan DOB, tetapi juga semakin memperkuat pengaruh dan kekuasaan elit lokal di daerah.

Beberapa lembaga kemudian mengkaji permasalahan tersebut dengan mengadakan berbagai macam studi dan penelitian untuk mengevaluasi pelaksanaan program pembangunan di DOB. Studi evaluasi yang dilakukan oleh Kemendagri dan beberapa lembaga lainnya lebih difokuskan pada bidang ekonomi, keuangan, pelayanan publik, aparatur pemerintah daerah dan beberapa aspek lainnya. Penggunaan aspek, indikator dan kriteria tersebut didasarkan pada Peraturan Pemerintah (PP) No. 129 Tahun 2000 tentang Persyaratan Pembentukan dan Kriteria Pemekaran, Penghapusan dan Penggabungan Daerah. Indikator yang terdapat dalam PP No.129 tahun 2000 juga menjadi dasar penilaian terhadap usulan pemekaran daerah. Di dalam PP ini, setidaknya terdapat sekitar 7 kriteria dan 43 sub indikator yang menjadi persyaratan pemekaran daerah.

Hasil studi evaluasi yang dilakukan oleh Badan Perencanaan Pembangunaan Nasional (BAPPENAS) bekerja sama dengan United Nations Development Programme (UNDP) mengungkapkan bahwa masalah umum yang dihadapi oleh DOB dari sektor ekonomi yaitu pembagian potensi ekonomi masih belum merata dan beban penduduk miskin lebih tinggi. Selain itu, tingkat pertumbuhan ekonomi DOB masih lebih rendah jika dibandingkan dengan pertumbuhan ekonomi di daerah induk. Pertumbuhan ekonomi DOB cenderung fluktuatif ketimbang daerah induk yang relatif stabil dan meningkat.

Hasil studi evaluasi yang dilakukan oleh Deputi Bidang Pengembangan Regional dan Otonomi Daerah BAPPENAS tahun 2008 mengungkapkan bahwa pada aspek ekonomi, 
pemekaran daerah belum secara optimal dapat mendorong berkembangnya sumber-sumber pertumbuhan ekonomi. Hasil analisis dari studi evaluasi tersebut juga menyimpulkan bahwa daerah pemekaran relatif tidak mampu meningkatkan kesejahteraan masyarakat secara optimal. Bahkan dalam beberapa hal mereduksi kesejahteraan masyarakat pada daerah-daerah pemekaran.

Sama halnya dengan apa yang terjadi di daerah lain, pertumbuhan ekonomi di Sulawesi Barat masih cenderung fluktuatif. Berdasarkan Laporan Analisis Pembangunan Wilayah Provinsi Sulawesi Barat Tahun 2015, selama kurun waktu 2010-2014 pendapatan perkapita di Provinsi Sulawesi Barat cenderung meningkat, namun masih berada di bawah pendapatan perkapita nasional. Hal ini menunjukkan tingkat kesejahteraan penduduk Sulawesi Barat relatif lebih rendah secara nasional.

Jika pada tahun 2010 rasio PDRB perkapita Provinsi Sulbar dan PDB Nasional sebesar 51,27 persen, maka pada tahun 2014 rasionya meningkat menjadi 55,06 persen. Apabila pertumbuhan penduduk antar provinsi tidak terlalu berbeda jauh, kinerja rata-rata provinsi lain berkembang lebih besar daripada Sulawesi Barat. Besarnya PDRB perkapita yang menunjukkan tingkat kesejahteraan di Provinsi Sulawesi Barat relatif meningkat namun tidak secara riil menunjukkan kesejahteraan masyarakat di wilayah tersebut.

Laporan tersebut juga menunjukkan bahwa kinerja perekonomian Sulawesi Barat tahun 2011-2014 cenderung mengalami penurunan. Pada tahun 2011-2013 pertumbuhan ekonomi menurun dari 10,73 persen pada tahun 2010 menjadi 6,94 persen pada tahun 2013, kemudian meningkat lagi menjadi 8,73 pada tahun 2014 . Selama kurun waktu tersebut laju pertumbuhan rata-rata Sulawesi Barat sebesar 8,91 persen, berada di atas rata-rata nasional 5,9 persen.

Walaupun pertumbuhan ekonomi Provinsi Sulawesi Barat cukup tinggi, namun hal tersebut masih belum bisa berdampak signifikan terhadap pengurangan angka penduduk miskin. Selama kurun waktu 2007 hingga 2014 persentase penduduk miskin di Sulawesi Barat berkurang sebesar 6,76 persen akan tetapi angka tersebut masih berada di atas rata-rata angka kemiskinan di tingkat nasional.

Perencanaan pembangunan ekonomi dianggap sebagai cara untuk memperbaiki kualitas pengelolaan sumber daya yang ada baik sumber daya manusia maupun sumber daya alam. Berbagai macam proyek pembangunan infrastruktur kemudian dijalankan untuk mendukung stabilitas di daerah tersebut. Namun, banyak daerah pemekaran baru di Indonesia yang gagal mengimplementasikan kebijakan di bidang politik, ekonomi, dan sosial budaya sesuai tuntutan dan harapan masyarakat (Maldun, 2015).

Salah satu penyebab yang mengakibatkan kebijakan penanggulangan kemiskinan di Indonesia kurang efektif adalah karena tidak adanya sinergi program penanggulangan kemiskinan yang terarah, terpadu, dan berkelanjutan sebagai akibat dari masih adanya ego sektoral dan tumpang tindihnya tugas pokok dan fungsi antar Satuan Kerja Perangkat Daerah (Huraerah, 2013). Selain itu, Pemerintah Daerah dan DPRD dalam penyusunan, pembahasan dan penetapan APBD kurang peka terhadap penanggulangan kemiskinan dalam arti APBD tidak pro aktif (masyarakat miskin). Hal ini terlihat dari postur anggaran khususnya belanja daerah dan pembiayaan daerah relatif masih kecil kurang signifikan dalam penanggulangan kemiskinan (Nawawi, 2015). Hambatan komunikasi internal yang dihadapi oleh direktorat pelaksanaan anggaran meliputi adanya perbedaan persepsi antara pimpinan dan bawahan terhadap pelaksanaan kegiatan pemerintahan. Kemudian terbatasnya praktik sharing informasi antara pihak manajemen kepada pegawai pelaksana. Gaya kepemimpinan atasan juga berpengaruh dalam setiap pelaksanaan kegiatan (Harivarman, 2017).

Jika ditinjau dari aspek ekonomi, kebijakan otonomi daerah bertujuan untuk pemberdayaan kapasitas daerah dalam meningkatkan proses pembangunan, yang pada akhirnya diharapkan dapat meningkatkan kesejahteraan masyarakat di daerah (Ahmad, 2011). Namun realitas yang terjadi saat ini, sistem pemerintahan daerah masih dihadapkan pada persoalan ego sektoral. Hal tersebut kemudian berdampak pada proses komunikasi yang terjadi di antara unsur OPD dalam setiap penyelenggaraan sistem tata kelola pemerintahan daerah. Kondisi inilah yang akhirnya dapat mempengaruhi upaya pemerintah daerah dalam mencapai tujuan pembangunan yang diharapkan khususnya dalam hal pengentasan kemiskinan. 
Selama ini ini evaluasi terhadap pelaksanaan otonomi daerah terutama untuk daerah otonomi baru yang dilakukan oleh pemerintah pusat cenderung dilakukan dengan membaca dokumen (desk evaluation), dan kurang memperhatikan kondisi riil di masyarakat. Akibatnya evaluasi dirasa kurang efektif dalam rangka pembinaan sebuah daerah. Diperlukan model evaluasi dalam rangka memperbaiki proses dan mekanisme pembentukan daerah otonom baru di masa yang akan datang (Katharina, Pahlevi, Lindawaty, \& Darmaningtias, 2016).

Program yang menjadi pembahasan dalam penelitian ini adalah Program Marasa (Mandiri, Cerdas, dan Sehat). Program Marasa merupakan program prioritas yang disusun berdasarkan turunan dari visi misi gubernur dan wakil gubernur Provinsi Sulawesi Barat untuk periode tahun 2017 hingga 2022.

Program Marasa dirumuskan dengan mengintegrasikan beberapa program lintas sektor yang dirumuskan oleh masing-masing Organisasi Perangkat Daerah (OPD) yang terkait. Fokus dalam penelitian ini adalah untuk menganalisis bagaimana hubungan dan proses kordinasi antar OPD dalam mengelola perencanaan program Marasa.

Penelitian ini bertujuan untuk menggambarkan sosiogram atau struktur jaringan komunikasi Organisasi Perangkat Daerah Pemerintah Provinsi Sulawesi Barat dalam mengelola perencanaan Program Marasa. Pada gulirannya hasil penelitian diharapkan menjadi rekomendasi bagi penyusunan strategi komunikasi efektif antarinstansi pemerintahan.

\section{METODE PENELITIAN}

Jenis penelitian ini adalah kuantitatif deskriptif dengan menggunakan metode analisis jaringan komunikasi. Analisis jaringan komunikasi adalah metode penelitian untuk mengidentifikasi struktur komunikasi dalam suatu sistem, di mana data relasional tentang arus komunikasi dianalisis dengan menggunakan beberapa jenis hubungan interpersonal sebagai unit analisis (Eriyanto, 2014).

Secara umum, analisis jaringan berfokus pada hubungan antara manusia dan bukan pada karakteristik orang. Hubungan ini dapat terdiri dari perasaan orang terhadap satu sama lain, pertukaran informasi, atau pertukaran yang lebih nyata seperti barang dan uang. Dengan memetakan hubungan ini, analisis jaringan membantu mengungkap pola komunikasi emergen dan informal yang ada dalam sebuah organisasi, yang kemudian dapat dibandingkan dengan struktur komunikasi formal (ZwijzeKoning \& Jong, 2005).

Subjek dalam penelitian ini adalah unsur-unsur OPD yang bertanggung jawab dalam pengelolaan perencanaan Program Marasa Provinsi Sulawesi Barat. Teknik penentuan informan (teknik sampling) yang digunakan dalam penelitian ini adalah teknik snowball sampling. Penarikan sampel dengan menggunakan teknik snowball dimulai dari aktor (kecil) yang kemudian terus menerus membesar hingga jumlah sampel mencukupi (Eriyanto, 2014). Adapun sampel awal yang digunakan dalam penelitian ini dimulai dari unsure pimpinan masing-masing OPD yang terlibat dalam pengelolaan perencanaan Program Marasa.

Data dalam penelitian ini diperoleh melalui tiga cara, yaitu (1) wawancara menggunakan kuisioner terbuka, (2) observasi dan (3) dokumen arsip. Jenis analisis jaringan komunikasi yang digunakan dalam penelitian ini terdiri dari dua jenis, yaitu analisis jaringan utuh dan analisi jaringan yang berpusat pada ego (ego networks). Level analisis jaringan dalam penelitian ini berada pada level sistem.

Teknik wawancara yang digunakan pada

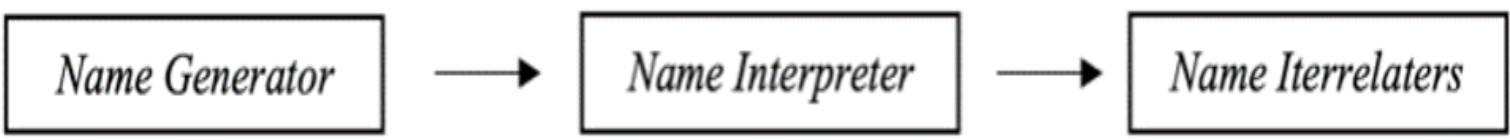

Sumber: Eriyanto, 2014

\section{Gambar 1 Alur Kuisioner}


bagian ini dilakukan dengan cara terstruktur yaitu dengan menggunakan kuisioner terbuka. Data wawancara yang didapatkan melalui kuisioner akan digunakan sebagai data primer untuk proses input pengolahan data serta perhitungan struktur jaringan komunikasi dengan menggunakan aplikasi UCINET versi 660. Untuk kuisioner penelitian jaringan akan dibagi menjadi tiga bagian, dapat dilihat pada gambar 1 .

\section{HASIL DAN PEMBAHASAN}

Proses perencanaan Program Marasa memiliki hierarki sesuai dengan tingkatan dalam struktur organisasi pemerintahan daerah. Perencanaan awal akan dilakukan pada level OPD Provinsi yang dikoordinir oleh Badan Perencana Pembangunan Daerah (BAPPEDA) Provinsi Sulawesi Barat. Setelah perencanaan pada level OPD provinsi selesai, perencanaan selanjutnya akan dilaksanakan pada level daerah kabupaten dengan mensinkronkan programprogram yang telah disusun oleh OPD Provinsi.

Berdasarkan pertimbangan di atas, analisis Perencanaan program Marasa kemudian dibagi ke dalam beberapa level struktur jaringan komunikasi. Hal ini dilakukan guna memetakan sejauh mana hubungan antar OPD baik pada level provinsi maupun dengan OPD pada level kabupaten. OPD yang menjadi objek analisis telah diberi kode unik masing-masing untuk mempermudah proses analisis data. Sementara itu, untuk proses analisis data dalam penelitian ini menggunakan Aplikasi UCINET versi 660. Berdasarkan hasil analisis dan olah data yang dilakukan oleh peneliti, struktur jaringan komunikasi yang terjadi dalam proses interaksi antar OPD provinsi dapat dilihat pada sosiogram gambar 2.

Kepadatan jaringan secara keseluruhan pada level komunikasi antar OPD Provinsi Sulawesi Barat sebesar 0,381 atau 38\%. Angka tersebut menunjukkan bahwa kepadatan jaringan komunikasi antara OPD Provinsi Sulawesi Barat tidak tinggi. Masing-masing OPD hanya terhubung kurang dari $50 \%$, artinya beberapa OPD tidak saling terhubung satu sama lain dalam setiap proses perencanaan Program Marasa. Data ini juga menunjukkan bagaimana karakteristik dari hubungan antara OPD. Masing-masing OPD akan saling terhubung jika terdapat tugas pokok, fungsi dan wewenang dalam satu bidang yang sama.

Hasil dari perhitungan UCINET menunjukkan diameter dari struktur jaringan komunikasi antar OPD Provinsi Sulawesi Barat adalah dua. Jarak terjauh (maksimal) dari aktor

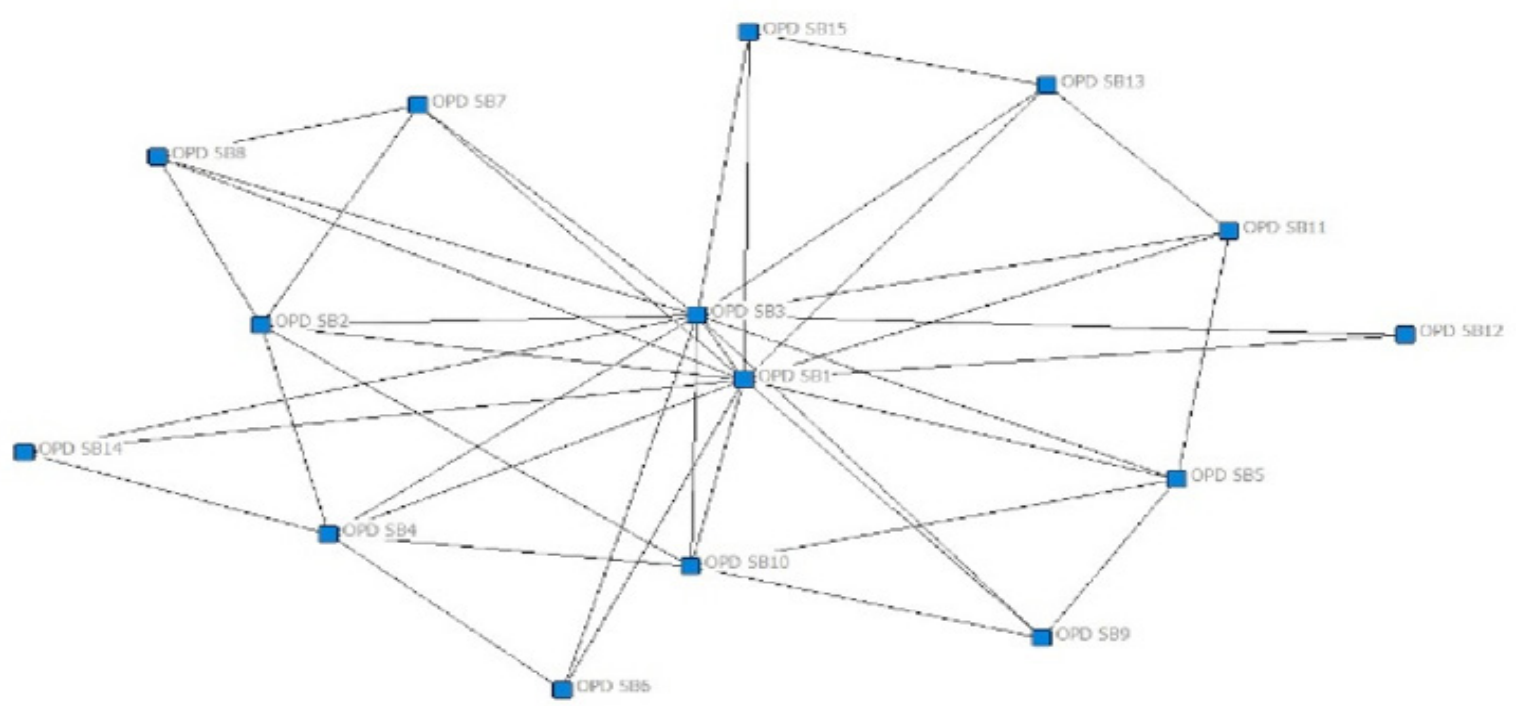

Sumber: Analisis data peneliti menggunakan aplikasi UCINET versi 660, 2018

Gambar 2 Sosiogram jaringan utuh OPD Provinsi Sulawesi Barat 


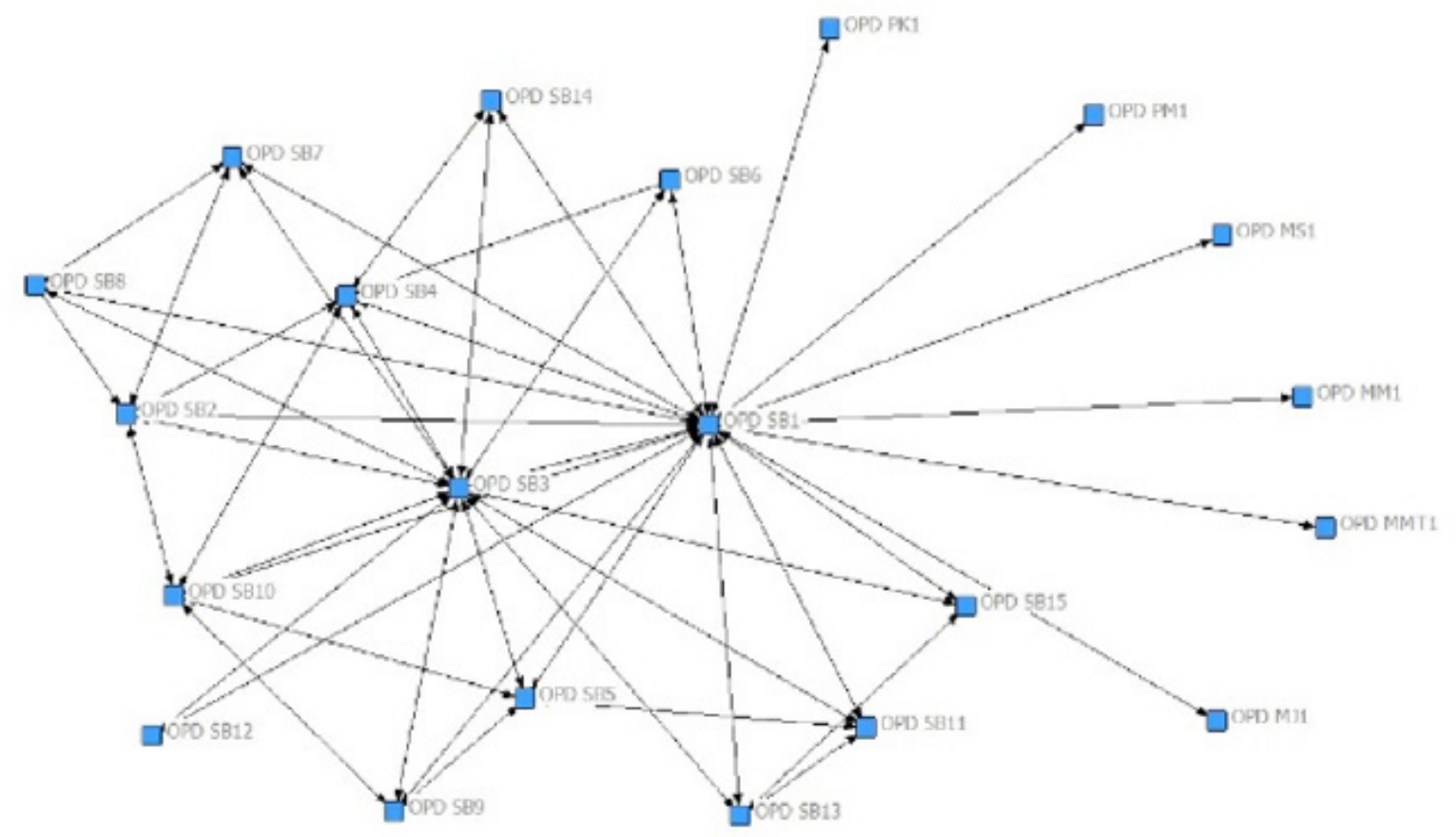

Sumber: Analisis data peneliti menggunakan aplikasi UCINET versi 660, 2018

Gambar 3 Sosiogram Jaringan Ego Bappeda Provinsi Sulawesi Barat

(OPD) dalam jaringan sebanyak dua langkah. Sementara jumlah total anggota jaringan yang dianalisis adalah 15. Hal ini menunjukkan bahwa terdapat hierarki dalam jaringan antar OPD Provinsi Sulawesi Barat. Artinya beberapa OPD yang ingin berhubungan dengan OPD lain perlu berkordinasi terlebih dahulu dengan OPD yang lainnya.

Terdapat dua titik sentral dalam jaringan komunikasi antar OPD Provinsi Sulawesi Barat, yaitu Badan Perencana Pembangunan Daerah (Bappeda/ OPD SB1) serta Dinas Pemberdayaan Masyarakat dan Desa (DPMD/ OPD SB3). Masing-masing dari kedua OPD tersebut memiliki data tingkatan (degree) sebesar 14 dari total anggota jaringan yang dianalisis. Data ini memperlihatkan bahwa OPD SB1 dan OPD SB2 berinterkasi dengan semua OPD yang terlibat dalam proses perencanaan Program Marasa. Kedua OPD ini juga memiliki angka keperentaraan (betweenness) dengan skor sebesar 60.

Meskipun menjadi titik sentral dalam proses perencanaan Program Marasa, namun kedua OPD tersebut memiliki peran yang berbeda dalam struktur jaringan komunikasi antar OPD Provinsi Sulawesi Barat. Bappeda berperan sebagai opinion leader yang memiliki pengaruh dalam menentukan program mana saja yang dapat diintegrasikan ke dalam Desa Marasa. Selain sebagai opinion leader, Bappeda juga berperan sebagai broker yang menyampaikan informasi terkait penyusunan program Marasa ke OPD yang lainnya. Berbeda dengan Bappeda, DPMD hanya berperan sebagai gate keepers. Perbandingan struktur jaringan masing-masing OPD tersebut dapat dilihat pada sosiogram gambar 3.

Dari sosiogram yang ditunjukkan pada gambar 3 dapat dilihat bahwa jaringan ego dari DPMD Provinsi Sulawesi Barat (OPD SB3) jauh lebih kompleks dibandingkan dengan jaringan ego Bappeda Provinsi Sulawesi Barat (OPD SB1). Hal ini terjadi karena jumlah klik atau aktor yang ada di sekitar struktur jaringan OPD SB3 sangat banyak. Klik-klik tersebut didominasi oleh Pemerintah Desa yang menjadi lokus dari Program Marasa. Sesuai dengan tugas pokok dan fungsi dari OPD SB3 yang menangani masalah terkait pemerintahan desa. Maka OPD SB3 berperan sebagai gatekepeers dan bridge yang menghubungkan antara desa dengan OPD yang terlibat dalam pengelolaan perencanaan Program Marasa. 


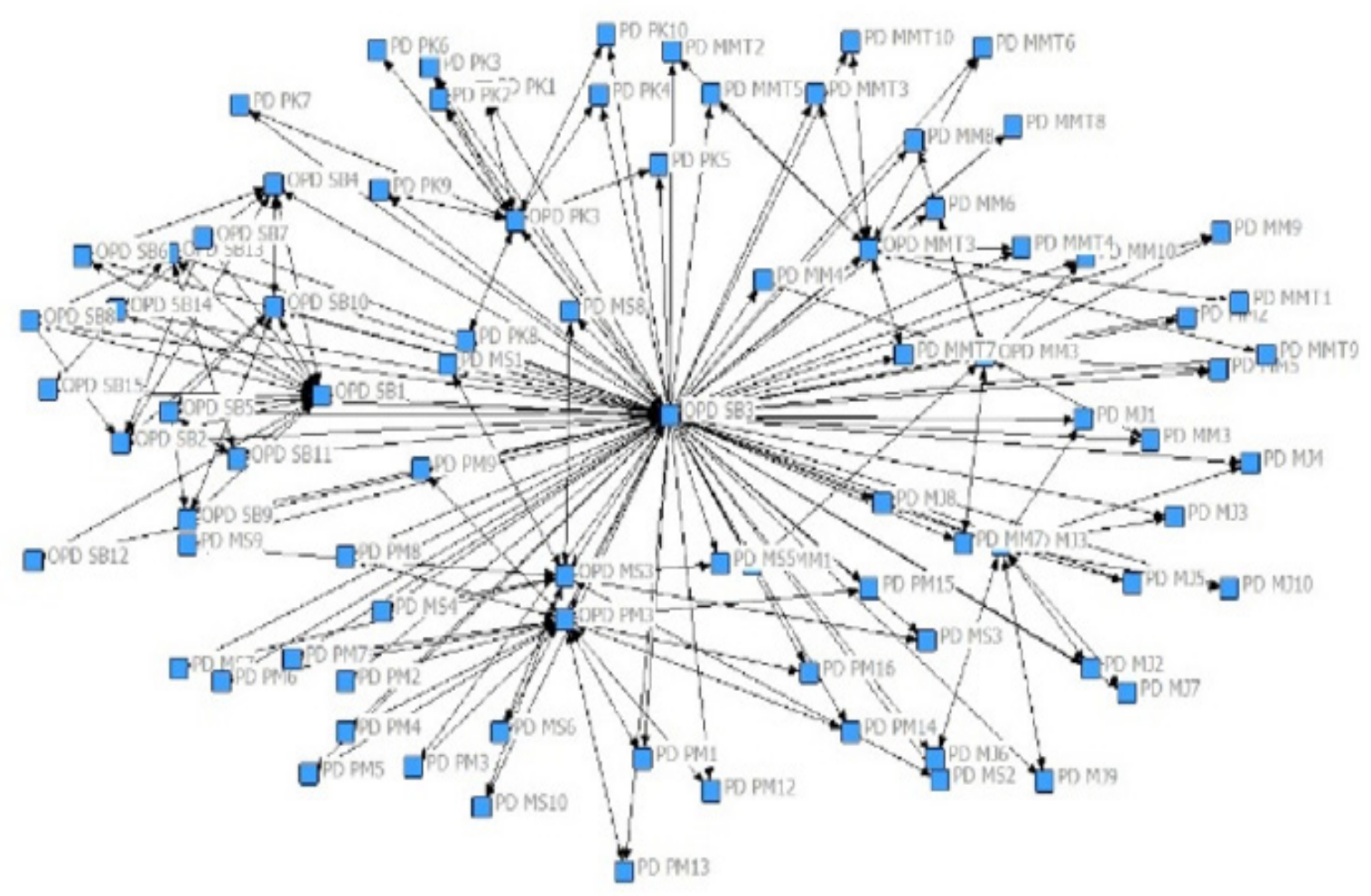

Sumber: Analisis data peneliti menggunakan aplikasi UCINET versi 660, 2018

Gambar 4 Sosiogram Jaringan Ego DPMD Provinsi Sulawesi Barat

Selain sentralitas, hasil analisis dalam strukturjaringan komunikasi antarOPD Provinsi Sulawesi Barat juga diperoleh data terkait kedekatan (closeness). Kedekatan dihitung dari total jarak yang dibutuhkan oleh aktor untuk menghubungi aktor lain dalam jaringan. Semakin rendah nilai kedekatan, maka semakin baik karena memperlihatkan jarak yang rendah dari aktor ke aktor yang lainnya (Eriyanto, 2014). Dalam struktur jaringan komunikasi antar OPD Provinsi Sulawesi Barat, terdapat dua OPD yang memiliki skor kedekatan terendah. Kedua OPD tersebut adalah Dinas Perpustakaan dan Kearsipan Daerah Provinsi Sulawesi Barat (OPD SB6) dan Dinas Pariwisata Provinsi Sulawesi Barat (OPD SB12).

OPD dengan angka keperentaraan (betweenness) terendah dalam struktur jaringan komunikasi antar OPD Provinsi Sulawesi Barat adalah Dinas Pendidikan dan Kebudayaan Provinsi Sulawesi Barat (OPD SB6), Dinas Pemberdayaan Perempuan, Perlindungan Anak, Pengendalian Penduduk dan Keluarga Berencana Provinsi Sulawesi Barat (OPD
SB8), Dinas Pertanian dan Peternakan Provinsi Sulawesi Barat (OPD SB9), Dinas Pariwisata Provinsi Sulawesi Barat (OPD SB12), Dinas Tenaga Kerja Provinsi Sulawesi Barat (OPD SB14) dan Dinas Komunikasi, Informatika, Persandian dan Statistik Provinsi Sulawesi Barat (OPD SB15). Keperantaraan (betweenness) menunjukkan sajauh mana peran OPD dalam menghubungkan relasi antar OPD yang terlibat dalam proses perencanaan Program Marasa.

Semakin tinggi angka keperantaraan (betweeenness) suatu OPD, maka semakin penting pula peran dari OPD tersebut. Bappeda dan DPMD merupakan aktor ego yang memiliki hubungan dengan 14 alter dari total 15 alter yang terdapat dalam jaringan komunikasi antar OPD Provinsi Sulawesi Barat. Kedua OPD ini juga memiliki link (ties) jaringan terbesar dengan total 54 link. Namun, meskipun memiliki jaringan ego terbesar, kepadatan dari dua aktor ego tersebut hanya sebesar 29,67\%. Angka tersebut merupakan skor kepadatan terkecil jika dibandingkan dengan OPD yang lainnya.

Jaringan dengan kepadatan tertinggi 
adalah Dinas Pendidikan dan Kebudayaan Provinsi Sulawesi Barat (OPD SB6), Dinas Pemberdayaan Perempuan, Perlindungan Anak, Pengendalian Penduduk dan Keluarga Berencana Provinsi Sulawesi Barat (OPD SB8), Dinas Sosial Provinsi Sulawesi Barat (OPD SB7), Dinas Pertanian dan Peternakan Provinsi Sulawesi Barat (OPD SB9), Dinas Pariwisata Provinsi Sulawesi Barat (OPD SB12), Dinas Tenaga Kerja Provinsi Sulawesi Barat (OPD SB14) dan Dinas Komunikasi, Informatika, Persandian dan Statistik Provinsi Sulawesi Barat (OPD SB15). Seluruh OPD tersebut memiliki jaringan ego dengan kepadatan maksimal 100\%.

Kepadatan jaringan menunjukkan perbandingan antara jumlah link (ties) dengan jumlah link yang mungkin muncul (Eriyanto, 2014). Meskipun masih terdapat beberapa jaringan dengan angka kepadatan maksimal, kecenderungan pola jaringan yang terbentuk dalam proses perencanaan Program Marasa adalah pola bintang. Hal tersebut dapat dilihat dari sosiogram pada Gambar 1 di mana hampir semua OPD Provinsi Sulawesi Barat saling terhubung satu sama lain.

Karakteristik penting lain yang dapat diamati dari jaringan yang terdapat pada struktur jaringan komunikasi antar OPD Provinsi
Sulawesi Barat adalah menghitung jarak ketika masing-masing OPD saling berhubungan. Untuk mengetahui karakteristik tersebut, dapat lakukan dengan melihat berapa besar diameter dari jaringan yang dianalisis. Hasil analisis pada struktur jaringan komunikasi antar OPD Provinsi Sulawesi Barat menunjukkan, langkah maksimal yang harus dilalui oleh OPD untuk saling terhubung dengan OPD lainnya adalah dua. Di lain sisi, terdapat pula OPD yang hanya membutuhkan satu langkah ketika akan menghubungi OPD lain.

Sebagai titik sentral dalam struktur jaringan komunikasi antar OPD Provinsi, Bappeda dan DPMD Provinsi Sulawesi Barat menempati posisi sebagai celah struktur. Data bisa disimpulkan berdasarkan hasil perhitungan yang diperoleh dari UCINET versi 660. Posisi ini memungkinan Bappeda dan DPMD Provinsi Sulawesi Barat untuk mengkontrol jaringan komunikasi antar OPD Provinsi. Karena kedua OPD tersebut bisa berhubungan dengan semua OPD serta mendapatkan keuntungan dari proses komunikasi yang terjadi.

Meskipun setiap OPD telah memiliki Pagu Anggaran pada Rencana Kerja Pembangunan Daerah (RKPD) masing-masing. Namun dalam perencanaan Program Marasa, pembahasan anggaran kembali dilakukan karena akan

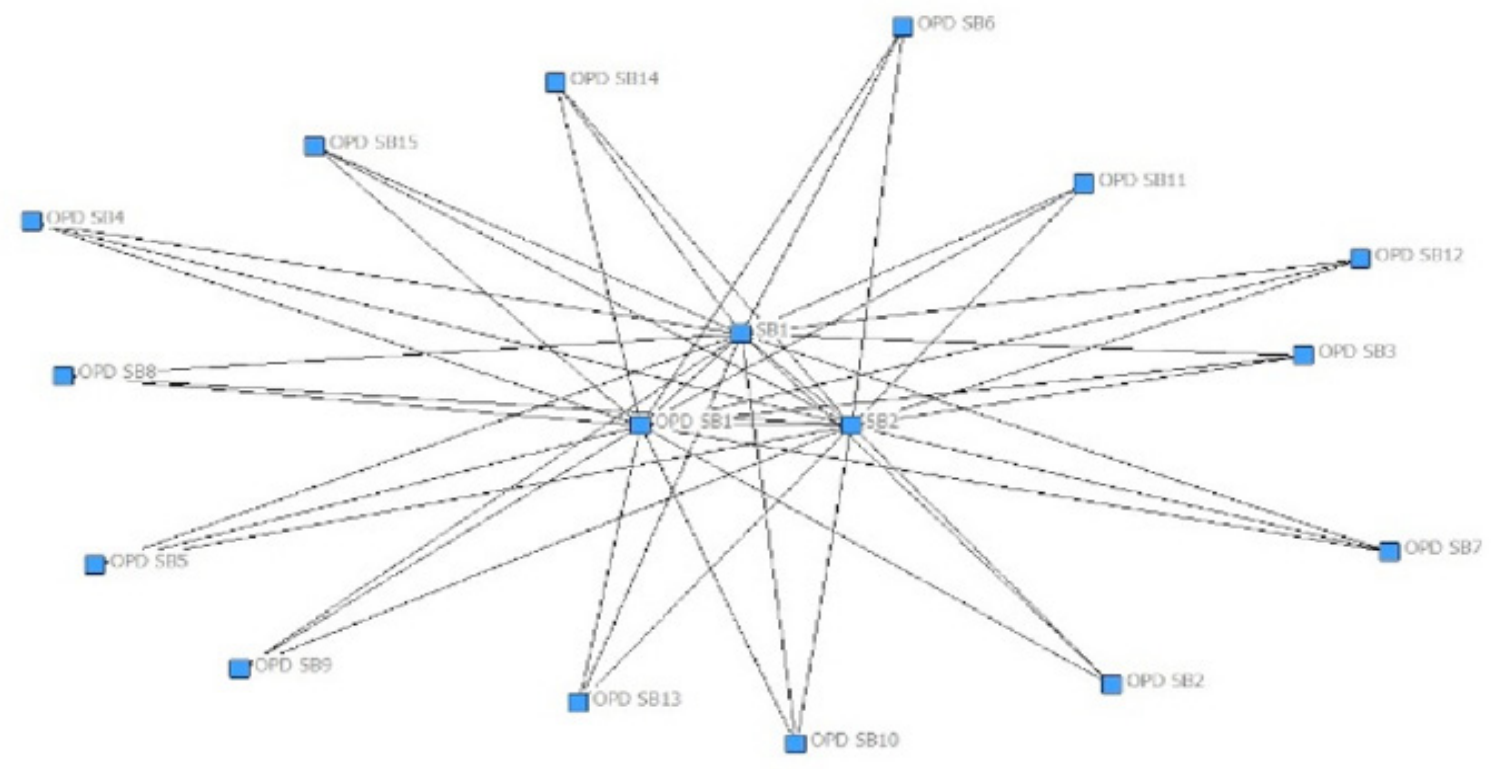

Sumber: Analisis data peneliti menggunakan aplikasi UCINET versi 660, 2018

Gambar 5 Sosiogram Jaringan Pembahasan Anggaran Pada Level OPD Provinsi 
dilakukan sinkronisasi anggaran terhadap program masing-masing program OPD. Hal ini terkait dengan adanya mekanisme bantuan keuangan khusus (BKK) yang akan mendukung program prioritas Marasa.

Wacana dominan yang selalu menjadi isu utama dalam perencanaan Program Marasa adalah pembahasan terkait anggaran. Pembahasan ini bisa jauh lebih rumit jika dibandingkan dengan pembahasan mengenai integrasi program yang diajukan oleh masingmasing OPD. Struktur jaringan pada proses ini juga turut melibatkan lembaga legislatif Dewan Perwakilan Rakyat Daerah (DPRD). Proses ini kemudian membentuk jaringan komunikasi yang pembahasannya fokus kepada perencanaan anggaran.

Struktur jaringan pada Gambar 5 menunjukkan tiga aktor yang menjadi titik sentral dalam proses pembahasan Program Marasa. Aktor tersebut terdiri dari Gubernur, DPRD dan Bappeda Provinsi Sulawesi Barat. Ketiga aktor tersebut memiliki size of network sebesar 16. Artinya masing-masing dari aktor tersebut terhubung dengan semua stakeholders yang terlibat dalam perencanaan anggaran Program Marasa. Aktor dari masing-masing OPD yang terlibat pada tahapan ini berasal dari pejabat eselon satu (kepala dinas), eselon dua (kepala bidang/seksi) dan beberapa pejabat eselon tiga (kasubag).

Komposisi pada struktur jaringan tersebut juga menunjukkan besarnya peran Bappeda Provinsi Sulawesi Barat sebagai OPD yang ikut merencanakan pembagian anggaran pada Program Marasa. Sehingga hal ini semakin memperjelas posisi Bappeda Provinsi Sulawesi Barat sebagai opinion leader dalam pengelolaan perencanaan Program Marasa. Meskipun di lain sisi Gubernur tetap masih memegang kekuasaan tertinggi dalam hierarki sistem pemerintahan daerah tingkat satu. Bappeda Provinsi tetap memainkan peran kunci sebagai OPD dengan tugas pokok dan fungsi sebagai lembaga yang mengatur segala macam perencanaan pembangunan di suatu daerah. Peran inilah yang dapat dimaksimalkan sebaik mungkin agar program yang direncanakan dapat berjalan dengan efektif.

Setelah mengetahui karakteristik dari struktur jaringan komunikasi OPD antar Provinsi, jaringan komunikasi yang selanjutnya akan dianalisis adalah struktur jaringan komunikasi antara OPD Provinsi dengan OPD Kabupaten. Perhitungan tersebut akan dilakukan dengan melibatkan beberapa OPD level

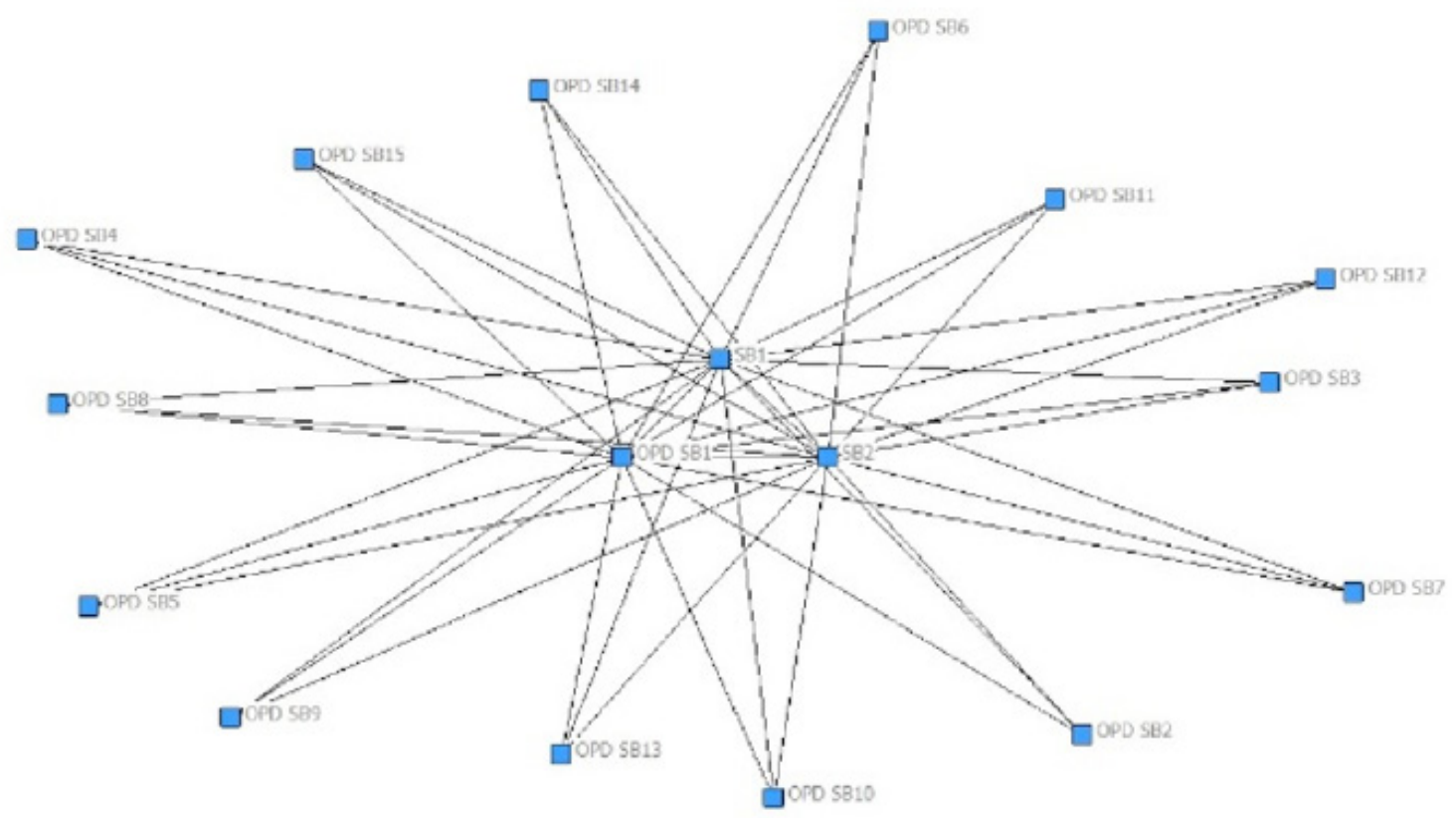

Sumber:Analisis data peneliti menggunakan aplikasi UCINET versi 660, 2018

Gambar 6 Sosiogram jaringan utuh OPD Provinsi Sulawesi Barat, OPD Kabupaten dan Pemerintah Desa Lokus Program Marasa 
kabupaten serta pemerintah desa yang menjadi lokus dalam program Marasa. Berdasarkan hasil analisis dengan menggunakan UCINET versi 660 , struktur jaringan komunikasi yang terjadi dalam proses interaksi antara OPD provinsi dengan OPD kabupaten dan pemerintah desa dapat dilihat pada sosiogram pada gambar 6 .

OPD dengan size of network terbesar pada struktur jaringan komunikasi OPD Provinsi dengan OPD kabupaten dan Pemerintah Desa Marasa adalah DPMD (OPD SB3). Secara keseluruhan aktor ini memiliki ukuran sebanyak 86.00 yang artinya DPMD terhubung dengan 86 alter lain. Sementara pada masing-masing level kabupaten, aktor dengan ukuran terbesar adalah Bappeda dari masing-masing kabupaten. Ukuran dari Bappeda kabupaten adalah sebesar 25.00 (OPD MJ1, OPD MS1, OPD MM1, OPD MMT1 dan OPD PK1) dan 31.00 (OPD PM1).

Bappeda dari masing-masing kabupaten memiliki peran sebagai bridge dalam proses komunikasi antara OPD Provinsi dengan OPD kabupaten dan pemerintah desa. Hasil uji analisis yang dikeluarkan oleh UCIENT versi 660 juga menunjukkan kepadatan (density) tertinggi berada Pemerintah Desa Marasa, yakni $66,67 \%$. Angka tersebut menunjukkan bahwa alter yang berada di sekitar ego pemerintah desa di seluruh kabupaten saling berinteraksi satu salam lain.

Jaringan komunikasi pada perencanaan Program Marasa merupakan proses penyebaran informasi yang terjadi baik di dalam organisasi itu sendiri (antar subsistem) maupun dengan organisasi lainnya. Perencanaan Program Marasa melibatkan organisasi pemerintahan eksekutif dan legislatif. Komunikasi yang terjadi pada perencanaan Program Marasa bersifat dua arah. Arah arus komunikasinya pun bisa bersifat vertikal, horizontal maupun diagonal. Pesan yang disampaikan umumnya berupa instruksi, pemberitahuan maupun perintah yang disampaikan oleh pimpinan ke bawahan, antar sesama pimpinan atau staf dengan mengikuti struktur hierarki yang terdapat dalam organisasi pemerintahan di Provinsi Sulawesi Barat.

Struktur jaringan komunikasi dalam perencanaan Program Marasa menunjukkan bagaimana lingkungan birokrasi memiliki jalur penyebaran informasi antar subsistem yang sangat rumit. Proses ini disebut sebagai sistem yang terdiferensiasi yang di dalamnya terdapat dua jenis lingkungan yaitu lingkungan umum bagi semua subsistem dan lingkungan khusus yang berbeda-berbeda bagi masing-masing subsistem (Luhmann, 1995).

Lingkungan umum dalam hal ini adalah organisasi secara keseluruhan dari struktur Pemerintahan Provinsi Sulawesi Barat yang terdiri dari beberapa OPD baik pada level provinsi maupun kabupaten. Kemudian lingkungan khusus masing-masing subsistem adalah lingkungan dari masing-masing OPD yang menjadi bagian dari struktur pemerintahan di Provinsi Sulawesi Barat. Diferensiasi merupakan mekanisme yang lumrah terjadi dalam sistem pemerintahan di Provinsi Sulawesi Barat. Karena ini merupakan cara dari sistem tersebut untuk beradaptasi dengan perubahanperubahan di dalam lingkungannya.

Diferensiasi juga merupakan cara dari suatu sistem menghadapi komplesitas lingkungan dengan membagi sistem ke dalam berbagai macam tugas spesifik seperti sistem ekonomi, sistem politik, sistem hukum dan sistem ilmu pengetahuan (Krause, 1999). Diferensiasi pada sistem pemerintah Provinsi Sulawesi Barat dalam menghadapi komplesitas lingkungannya adalah dengan adanya pembagian peran dari masing-masing subsistem dalam mengelola perencanaan Program Marasa.

Proses diferensiasi merupakan cara untuk meningkatkan kompleksitas suatu sistem, karena masing-masing subsistem dapat menjalin hubungan yang berbeda-beda dengan subsistemsubsistem yang lain (Ritzer, 2014). Hubungan tersebut dapat dilihat dari struktur jaringan komunikasi dalam pengelolaan perencanaan Program Marasa. Dimana setiap OPD dalam struktur Pemerintah Daerah Provinsi Sulawesi Barat merupakan lingkungan bagi OPD lainnya. Setiap hubungan yang terjadi di antara OPD Pemerintah Provinsi Sulawesi Barat adalah bentuk dari kompleksitas lingkungan birokrasi. Untuk menghadapi kompleksitas tersebut, sistem akan menjalankan proses reduksi dan penyeleksian terhadap segala macam informasi dan umpan balik yang terkait dengan pengelolaan perencanaan Program Marasa.

Proses reduksi dan penyeleksian informasi merupakan hal sentral dalam sistem komunikasi yang bertujuan untuk membuat lingkungan menjadi jelas dan pasti (Handaka \& Wahyuni, 2017). Arus komunikasi yang kurang baik dalam suatu unit kerja atau sistem menjadi merupakan salah satu penyebab terjadinya komunikasi 
yang tidak efektif (Irawan \& Venus, 2016).

Sistem komunikasi pemerintah Provinsi Sulawesi Barat telah memiliki mekanisme tersebut yang memungkinkan adanya proses penyebaran informasi dan umpan balik di antara subsistem di dalamya. Hal tersebut dapat dilihat dari adanya pembagian peran dari masingmasing OPD dalam pengelolaan perencanaan Program Marasa. Peran-peran tersebut juga secara jelas memperlihatkan bagaimana upaya dari sistem komunikasi pemerintah Provinsi Sulawesi Barat dalam beradaptasi dengan komplesitas lingkungannya.

Sistem komunikasi Pemerintah Daerah ProvinsiSulawesiBarattelahmampumembentuk dirinya sendiri di luar dari peran masing-masing subsistem(OPD). Pengorganisasian diri tersebut juga dapat disebut sebagai autopoiesis atau bagaimana jaringan-jaringan komunikasi OPD Provinsi Sulawesi Barat saling berinteraksi satu sama lain yang kemudian memproduksi dan membentuk dirinya. Pada dasarnya sistem sosial terdiri dari proses komunikasi dan peristiwa yang kemudian membentuk tatanan sehingga memunculkan kompleksitas dari lingkungan yang bersifat sementara. Istilah autopiesis kemudian digunakan pada sistem komunikasi pemerintah Provinsi Sulawesi Barat karena bentuk autopoiesis sering ditujukan kepada struktur yang telah tertata rapi dan stabil untuk jangka waktu yang lama (Luhmann, 1995).

\section{SIMPULAN}

Temuan dalam penelitian ini menunjukkan dinamika sistem komunikasi lembaga pemerintahan Provinsi Sulawesi Barat dalam mengelola perencanaan Program Marasa. Mulai dari struktur jaringan komunikasi, alur penyebaran informasi, aktor kunci hingga hambatan yang dapat mempengaruhi proses tersebut. Dinamika dalam sistem komunikasi pemerintah Provinsi Sulawesi Barat terjadi ketika terjadi proses diferensiasi di dalamnya. Diferensiasi merupakan mekanisme sistem komunikasi pemerintah Provinsi Sulawesi Barat dalam beradaptasi untuk menghadapi kompleksitas lingkungan. Proses diferensiasi terjadi pada proses penyebaran informasi baik formal maupun informal. Jalur penyebaran informasi tersebut tidak hanya menunjukkan proses penyebaran pesan, tapi juga menunjukkan pembagian peran serta posisi dari setiap aktor dalam membentuk dan mengirimkan pesan tersebut.

Hasil penelitian ini menunjukkan pembagian peran dari masing-masing subsistem yang terdapat dalam sistem komunikasi OPD Pemerintah Daerah Provinsi Sulawesi Barat. Dari temuan tersebut, terlihat aktor kunci dalam proses pengelolaan perencanaan Program Marasa dapat berasal dari beragam level jabatan eselon. Setiap anggota organisasi memiliki potensi pengaruh yang sama pada setiap proses perencanaan dan pengambilan keputusan di dalam organisasi.

Aktor kunci dalam pengelolaan perencanaan Program Marasa tidak sepenuhnya diperankan oleh pimpinan dalam hal ini gubernur, bupati, kepala dinas atau badan serta unsur pimpinan legislatif. Peran tersebut justru lebih banyak dimainkan oleh pejabat-pejabat yang berada pada level Eselon III dan IV. Selain para pejabat eselon tersebut, aktor di beberapa dinas bahkan diperankan oleh staf yang tidak memiliki jabatan eselon. Hal ini terjadi karena kerja yang berkaitan dengan perencanaan lebih banyak dilakukan oleh aktor-aktor yang berada pada wilayah tersebut.

Komunikasi merupakan salah satu elemen penting dalam setiap proses pengambilan keputusan di organisasi pemerintahan. Agar komunikasi yang dijalankan pemerintah dapat berjalan efektif, maka organisasi formal seperti lembaga pemerintah perlu mengubah gaya dan model komunikasi yang mereka gunakan. Proses perencanaan pesan, pemilihan saluran dan media komunikasi serta pendekatan dan gaya komunikasi merupakan beberapa hal penting yang perlu diperhatikan.

\section{DAFTAR PUSTAKA}

Abdullah, M. T. (2011). Menelaah kebijakan pemekaran daerah di Indonesia: suatu perspektif teori dan praktik. Spirit Publik, $7(1), 15-28$.

Ahmad, I. (2011). Disparitas hasil pembangunan kabupaten/kota sebelum dan sesudah otonomi daerah. Jurnal Ilmu Administrasi Negara, 11(2), 156-166.

Eriyanto. (2014). Analisis jaringan komunikasi: strategi baru dalam penelitian ilmu komunikasi dan ilmu sosial lainnya. Jakarta: Prenadamedia. 
Fibrianti, N. (2017). Dinamika aktor dalam persiapan pemekaran daerah Balanipa. Jurnal Magister Ilmu Politik Universitas Hasanuddin, 3(1), 34-44.

Fitrani, F., Hofman, B., \& Kaiser, K. (2005). Unity in diversity? The creation of new local governments in a decentralising Indonesia. Journal Bulletin of Indonesian Economic Studies, 41(1), 57-79. https://doi.org/ttps:// doi.org/10.1080/00074910500072690.

Handaka, T. \& Wahyuni, H. I. (2017). Interlasi subsistem komunikasi pemerintah dalam pengembangan kambing kaligesing di Purworejo. Jurnal Ilmu Komunikasi, 14(2), 203-220. https://doi.org/https://doi. org/10.24002/jik.v14i2.1137.

Harivarman, D. (2017). Hambatan komunikasi internal di organisasi pemerintahan. Jurnal Aspikom, 3(3), 508-519.

Huraerah, A. (2013). Strategi kebijakan penanggulangan kemiskinan di Indonesia (policy strategy of tackling poverty in Indonesia). Jurnal Pemberdayaan Komunitas, 12(1).

Irawan, D. \& Venus, A. (2016). Pengaruh iklim komunikasi organisasi terhadap kinerja pegawai kantor keluarga berencana Jakarta Barat. Jurnal Kajian Komunikasi, 4(2). https://doi.org/https://doi.org/10.24198/ jkk.v4i2.7367.

Katharina, R., Pahlevi, I., Lindawaty, D. S., \& Darmaningtias, D. S. (2016). Evaluasi terhadap pemekaran daerah dan potensi penggabungan daerah: kasus Kabupaten Sigi dan Kabupaten Tanjung Jabung Timur. Jakarta: Balai Pustaka.

Krause, D. (1999). Luhmann-lexikon. eine einführung in das gesamtwerk von niklas luhmann mit 27 abbildungen und über 500 stichworten. Stuttgart.

Luhmann, N. (1995). Social systems. Translated by John Bednarz, Jr. With Dirk Baecker. Stanford: Stanford University Press.

Maldun, S. (2015). Analisis implementasi kebijakan pemekaran daerah di kabupaten Mamuju Utara. Seminar Nasional "Revolusi Mental Dan Kemandirian Bangsa Melalui Pendidikan Ilmuilmu Sosial Dalam Menghadapi MEA 2015”.

Nawawi, J. (2015). Analisis hubungan DPRD dan pemerintah daerah dalam pembuatan kebijakan kemiskinan di provini Sulawesi Barat. Government: Jurnal Ilmu Pemerintahan, 8(1). Retrieved from http:// journal.unhas.ac.id/index.php/government/ article/view/99.

Sulaiman, S. (2017). Dinamika politik dalam proses pembentukan kabupaten Luwu Tengah. The Politics, 3(2).

Zwijze-Koning, K. H. \& Jong, M. D. T. de. (2005). Auditing information structures in organizations: a review of data collection techniques for network analysis. Organizational Research Methods, 8(4). 